\title{
A África no discurso colonial português
}

Regina Zilberman ${ }^{1}$

\begin{abstract}
The colonial discourse is depicted in the first productions of epic Portuguese literature such as the poems of Luís de Camões (Os Lusíadas) and Jerônimo Corte Real (O naufrágio do Sepúlveda). It returns, after the growth of capitalism in the nineteenth century, in the fiction of Eça de Queiroz (A correspondência de Fradique Mendes, A ilustre casa de Ramires), but it takes particular tinction to the extent that the novelist devises a utopia for Portuguese Africa.
\end{abstract}

Keywords: colonial discourse; Camões; Jerônimo Corte Real; Eça de Queiroz.

Resumo: O discurso colonial emerge nas primeiras produções épicas da literatura portuguesa, como os poemas de Luís de Camões (Os Lusíadas) e Jerônimo Corte Real (O naufrágio do Sepúlveda). Ele retorna, após a expansão do capitalismo no século XIX, na ficção de Eça de Queiroz ( $A$ correspondência de Fradique Mendes; A ilustre casa de Ramires), mas toma coloração particular na medida em que aquele romancista formula uma utopia para a África portuguesa.

Palavras-chave: discurso colonial; Camões; Jerônimo Corte Real; Eça de Queiroz.

\section{Poemas épicos e discurso colonial}

1. A África apresentou-se como objeto de desejo dos portugueses desde o século XIV, com projeções no século XV. Seus primeiros conquistadores, liderados por D. João I na conquista de Ceuta, em 1415, provavelmente já se autodesignavam portugueses, pois a nação e o Estado haviam tomado forma ainda no século XIII; mas esqueciam que muitos deles descendiam dos africanos, provenientes do norte ainda ocupado pelos árabes, que pretendiam dominar.

No começo do século XV, o foco eram as províncias árabes ou mouras, acusadas de heréticas conforme a literatura posterior procedeu, especialmente a dos séculos XVI e XVII. Mas, com o avanço sobre a costa africana ocidental, graças à ação de navegadores como Gil Eanes, em 1435, que contorna o cabo Bojador, Diogo Gomes, que ocupa o Cabo 


\section{Conexão Letras}

Verde, Diogo Cão, que chega ao rio Zaire, em 1482, e Bartolomeu Dias, que atinge o cabo das Tormentas, em 1487, outro objetivo mostra-se atraente: o comércio de escravos, próspero já no século XV.

Conforme observa Martin Page, em A primeira aldeia global, D. Henrique, o da Escola de Sagres, foi "o primeiro a promover o comércio de escravos oriundos da África Negra". ${ }^{2}$ Depois complementa, "antes da morte do infante D. Henrique, em 1460, cerca de 1000 escravos eram anualmente desembarcados em Lagos, vindo a constituir a maioria da população do Algarve e cerca de dez por cento da de Lisboa." ${ }^{3}$

Para justificar o avanço sobre o norte da África, aliás, nem sempre bem sucedido, os lusitanos encontraram uma justificativa na religião, sendo os árabes qualificados de mouros, heréticos e até de parceiros de Satanás. A poesia épica dos séculos XVI e XVII, a começar por Luís de Camões, foi fértil na variação com que empregava adjetivos pejorativos para qualificar o povo de onde parte de sua história procedia.

Também os homens de pele escura foram qualificados de modo específico, e "cafres" foi o substantivo escolhido para nomeá-los genericamente. O nome fora utilizado originalmente, conforme o Dicionário Aurélio, "pelos islamitas", que assim designavam "gentios e idólatras", por extensão "negros pagãos da África oriental”: "aplica-se, sobretudo, às populações bantas de Moçambique, da África do Sul e dos demais países do S. E. da África." Cafre, porém, significa, além do "natural ou habitante da Cafraria, denominação que, no passado, se dava à região entre o rio Kei e os limites da província de Natal, na África do Sul", uma "pessoa rude, bárbara, ignorante" ${ }^{4}$.

De um modo ou de outro, os africanos eram rebaixados por meio de uma substantivação depreciativa.

2. Os episódios ocorridos entre os séculos XIV e XVII, relativos ao processo de ocupação da África meridional pelos portugueses, constituíram matéria da poesia, da historiografia e dos relatos de viagem, aparecendo não apenas na epopeia de Camões, mas também nas Décadas, de João de Barros, inspiradores, conforme vários estudiosos desde o século XVII a XIX, de Os Lusíadas. ${ }^{5}$ Essa matéria compõe um corpus que se poderia observar sob a perspectiva do que Walter Mignolo define enquanto "discurso colonial", a saber, "todos os tipos de produção de discurso relacionado ou emergente de situações coloniais". ${ }^{6}$

É esse discurso que se acompanha, registrado em dois poetas coetâneos: Luís de Camões, já citado, em Os Lusíadas, e Jerônimo Corte Real, em O naufrágio do Sepúlveda, quando narram um mesmo acontecimento, sumariado no título da obra do segundo.

Luís de Camões, em Os Lusíadas, foi um dos que ajudaram a fixar em versos a denominação "cafre", ainda que em poucas oportunidades o substantivo apareça. Na primeira delas, no Canto V, é Adamastor, o sul-africano, habitante da região que geograficamente

2 PAGE, Martin. A primeira aldeia global. Trad. Gustavo A. Palma. Cruz Quebrada: Casa das Letras, 2008. p. 107. Cf. também VENANCIO, Renato Pinto. Cativos do Reino. A circulação de escravos entre Portugal e Brasil, séculos 18 e 19. São Paulo: Alameda, 2012.

3 PAGE Martin. Op. cit. p. 118.

4 Novo Dicionário Eletrônico Aurélio versão 7.0. 5. ed. Curitiba: Positivo, 2010.

5 Cf. DENIS, Ferdinand. Résumé de l'histoire littéraire du Portugal, suivi du Résumé de l'histoire littéraire du Brésil. Paris: Lecointe et Durey, Libraires, 1826.

6 MIGNOLO, Walter. Colonial and postcolonial discourse: Cultural critique or academic colonialism? Latin American Research Review, Vol. 28, No. 3. (1993), pp. 120-134. http://links.jstor.org/sici?sici=00238791\%281993\%2928\%3A3\%3C120\%3ACAPDCC\%3E2.0.CO\%3B2-V. Acesso em 14 de janeiro de 2008. 
poderia ser identificada à Cafraria, que o menciona, anunciando o triste episódio vivido por Sepúlveda e sua esposa, depois do naufrágio do barco comandado por aquele nobre português. Entre outras desgraças ocorridas ao casal, informa Adamastor:
Verão morrer com fome os filhos caros,
Em tanto amor gerados e nascidos;
Verão os Cafres, ásperos e avaros,
Tirar à linda dama seus vestidos;
Os cristalinos membros e perclaros
À calma, ao frio, ao ar, verão despidos,
Depois de ter pisada, longamente,
Cos delicados pés a areia ardente. ${ }^{7}$

$\mathrm{Na}$ segunda oportunidade, igualmente os cafres são mencionados por meio de uma profecia. Agora é a divina Tétis, no Canto X, que anuncia o destino de Francisco de Almeida, militar e então ex-vice governador da Índia, que morreu em confronto com os nativos do sul da África:
Ali, Cafres selvagens poderão
O que destros imigos não puderam;
E rudos paus tostados sós farão
O que arcos e pelouros não fizeram.
Ocultos os juízos de Deus são;
As gentes vãs, que não nos entenderam,
Chamam-lhe fado mau, fortuna escura,
Sendo só providência de Deus pura. ${ }^{8}$

Sublinhe-se a adjetivação empregada para qualificar as criaturas que não apresentam outra identidade: Leonor de Sá é atacada por indivíduos "ásperos e avaros", Francisco de Almeida, por "selvagens". Os primeiros comportam-se como voyers, testemunhando a "linda dama" despir-se; os segundos empregam "rudos paus".

$\mathrm{Na}$ epopeia assinada por Corte Real, O naufrágio e lastimoso sucesso da perdição de Manuel de Sousa Sepúlveda, publicada postumamente, em 1594, essas imagens se adensam. O poema narra o naufrágio do título e as tentativas do fracassado comandante uma espécie de Vasco da Gama raté - para sobreviver na região onde soçobrara seu barco, entre os atuais África do Sul e Moçambique, estabelecer contato com os locais e salvar a família. Nenhuma dessas providências dá certo.

As qualificações da população local são todas negativas, e citam-se aqui alguns trechos. Nesta cena, o narrador descreve a chegada dos nativos:

Correndo a pressa vem do mato espesso

Cafres, que roubar tem só por ofício

Saltam matos daqui, e dali saltam

Com terríveis medonhas e altas gritas. ${ }^{9}$.

7 CAMÕES, Luís de. Os Lusíadas. São Paulo: Jackson, 1956. p. 178-179.

8 CAMÕES, Luís de. Op. cit. p. 339.

9 CORTE REAL, Jerônimo. Naufrágio de Sepúlveda. In: Obras. Introdução e revisão de M. Lopes de Almeida. Porto: Lello \& Irmãos, 1979. p. 849. 
Nesta outra cena, tal como mostrara Camões, Leonor é exposta ao olhar dos inimigos, que não se constrangem em contemplar a nudez da moça:

Chegam com denodada fúria os cafres
A desarmada gente que num ponto
Por eles despojada foi de todo
Sem roupa lhes ficar, ou cobertura.
Tal fica Leonor, qual na montanha
Troiana, a Citereia foi julgada
Pelo frígio pastor, e das formosas
Três, o preço levou com razão justa. ${ }^{10}$.

Repetem-se a selvageria, a barbárie e a baixa tecnologia por parte desse grupo étnico que, de certo modo, se converte em metonímia do lugar onde reside: os "cafres" pertencem à África e estão autorizados a traduzi-la simbolicamente. Mas, ao fazê-lo, desqualificam-na, destacando-se as propriedades indicadas: a primitividade no comportamento, na linguagem e na sociabilidade. Com isso, ficam praticamente desprovidos de humanidade.

\section{Outra África, outro discurso?}

A África representada por Camões e Corte Real, na esteira dos historiadores do século XVI, ainda não é problema, porém, ainda que faça vítimas, como o malfadado Sepúlveda e sua família. Pelo contrário, mostra-se bastante rentável, já que continuou a sustentar a lucratividade do tráfico de negros, iniciado no século XV, antes da exploração da mão de obra escrava nas plantations da América, estendendo-se até meados do século XIX, e até mesmo o alvorecer do século XX. E, quando esse se tornou ilegal, aquele continente acolheu as expectativas portuguesas, já que era o que restava do império lusitano conquistado entre os séculos XV e XVI.

O século XIX desvenda, porém, outra África, porque se trata agora de nova etapa do imperialismo. Ao imperialismo dos séculos XIV ao XVII interessam as riquezas da América; ao do século XIX, as matérias-primas da África, cuja exploração torna-se vital para a indústria europeia em expansão. Portugal e Espanha dominaram o primeiro movimento; agora a Inglaterra vitoriana impõe as regras.

Não apenas os povos africanos são vítimas do novo estágio da economia capitalista, que distribui o território entre colônias de ingleses, e, em menor proporção, de franceses, alemães, belgas, italianos, conforme a geografia nacional do Velho Continente a partir de meados do século XIX. Também os portugueses são objeto do poder britânico, como mostra o processo que levou ao Ultimato, em 1890, na sequência da Conferência de Berlim, de 1884-1885.

Dois mapas do período indicam a nova distribuição geográfica do continente africano, publicados em $O$ Ocidente: revista ilustrada de Portugal e do estrangeiro. ${ }^{11}$ Vale observá-los, porque dão conta da percepção do problema àquele momento histórico.

O primeiro deles, publicado em $1^{\circ}$ de janeiro de 1890 , exibe as possessões portuguesas na África:

10 CORTE REAL, Jerônimo. Op. cit. p. 849-850.

11 Cf. http://pt.wikipedia.org/wiki/O_Ocidente. Acesso em 3 de novembro de 2011. 


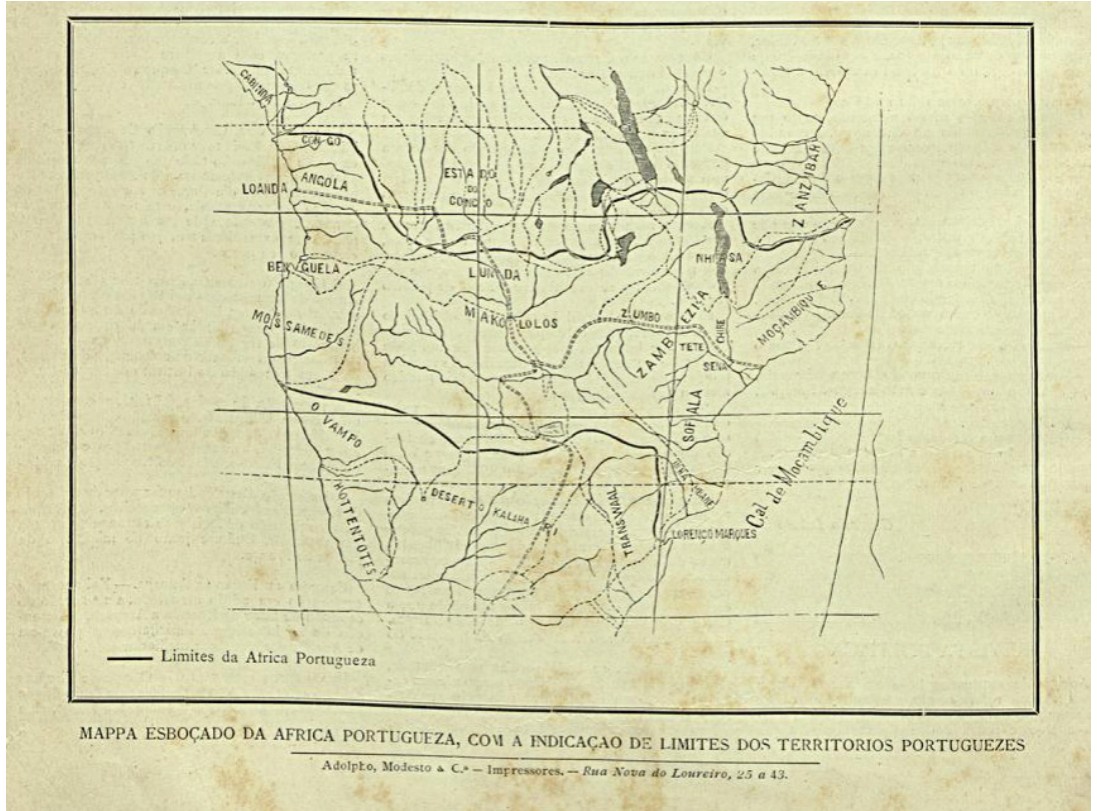

Fonte: http://hemerotecadigital.cm-lisboa.pt/OBRAS/Ocidente/1890/N397/N397_item1/P8.html ${ }^{12}$

A distribuição geográfica pretendida por Portugal se evidencia no chamado "Mapa cor-de-rosa", proposto por volta de 1886 e aqui copiado:

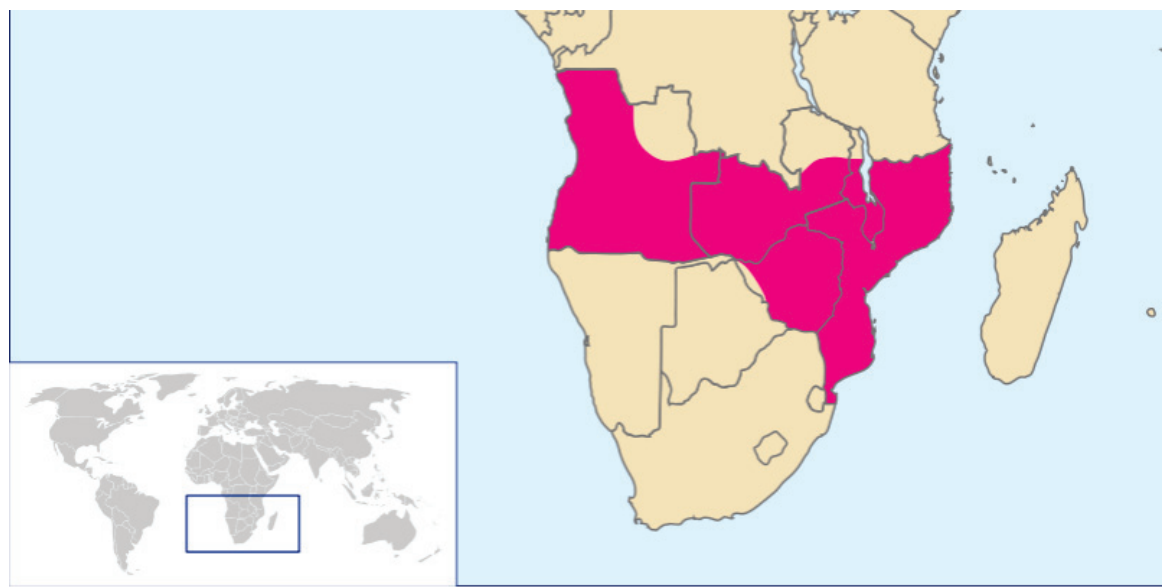

Figura 2 - África portuguesa no século XIX

Fonte: http://pt.wikipedia.org/wiki/Ficheiro:Mapa_Cor-de-Rosa.svg. ${ }^{13}$

No mapa a seguir, também extraído de O Ocidente, periódico português, aparecem as regiões reivindicadas pelos britânicos:

12 Acesso em 3 de novembro de 2011.

13 Acesso em 3 de novembro de 2011. 


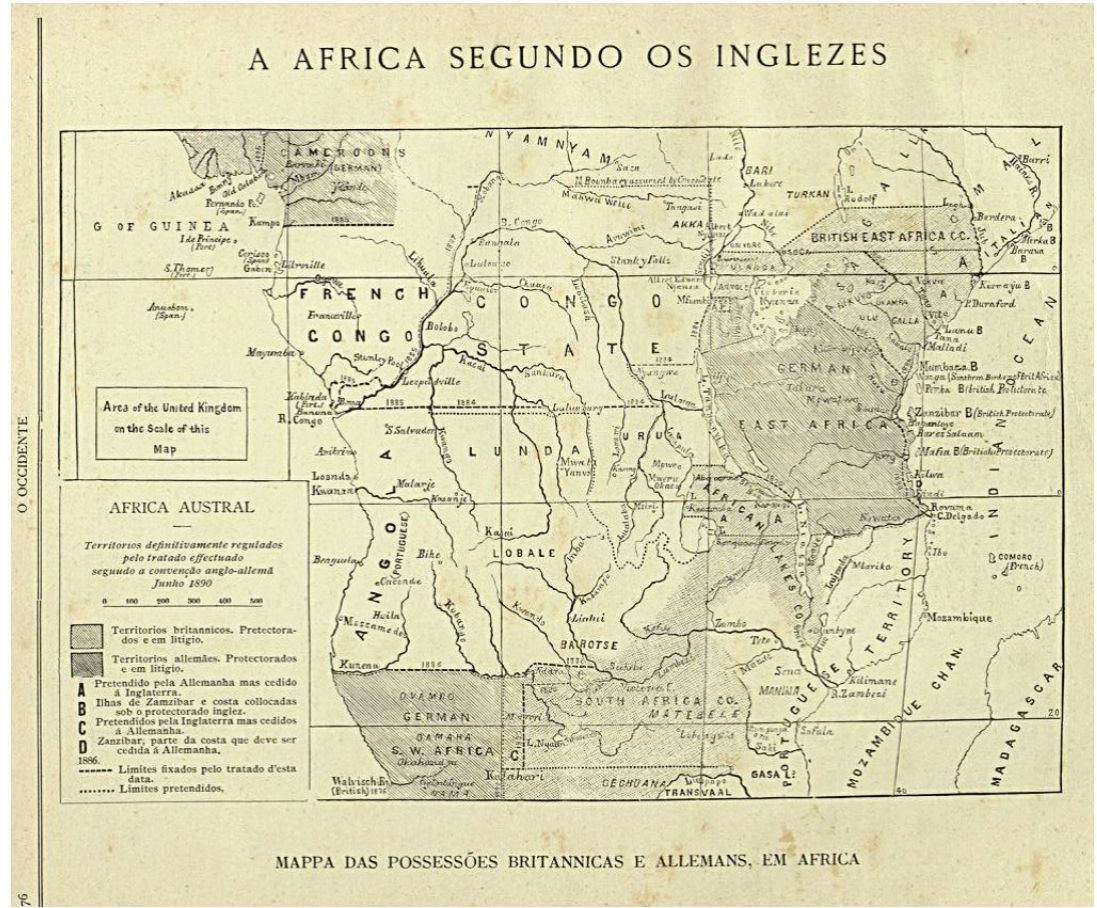

Fonte: http://hemerotecadigital.cm-lisboa.pt/OBRAS/Ocidente/1890/N418/N418_item1/P8.html ${ }^{14}$

O novo estágio das discussões sobre a África, opondo britânicos e portugueses, repercute sobre a literatura, onde se verifica não apenas a retomada da representação da população local, mas também a introdução daquele espaço continental como matéria discursiva. Assim, a África se faz presente em obras de Eça de Queiroz, produzidas ao final do século XIX, na esteira das consequências do Ultimato dos ingleses, de 11 de janeiro de 1890 .

A correspondência de Fradique Mendes começou a ser publicada na imprensa em 1888, complementando-se sua edição em 1890, na Revista de Portugal, periódico dirigido por Eça de Queiroz. Mas a impressão do livro é póstuma, datando de 1900. Na maioria de suas cartas, Fradique dá conta de suas viagens, que se estendem pela Europa e pela América, chegando ele "ao Brasil, aos Pampas, ao Chile e à Patagônia." ${ }^{15}$ A África não ficou de fora de suas andanças, pois o narrador, que o apresenta na primeira parte do livro, destaca seu trânsito pela África Austral e pela "na região do Zambeze", onde recolheu "notas muito flagrantes, muito vivas, sobre os cultos nativos - que são divinizações dos chefes mortos, tornados pela morte mulungus, espíritos dispensadores das coisas boas e más, com residência divina nas cubatas e nas colinas onde tiveram a sua residência carnal". ${ }^{16}$

Antes, porém, o narrador refere-se a seu encontro com Fradique Mendes no Cairo, memória ficcional que remete provavelmente à viagem do próprio Eça de Queiroz à Palestina e ao Egito, por ocasião da inauguração do Canal de Suez: ${ }^{17}$

14 Acesso em 3 de novembro de 2011.

15 QUEIROZ, Eça de. A correspondência de Fradique Mendes. Lisboa: Livros do Brasil, s. d. p. 53.

16 QUEIROZ, Eça de. Op. cit. p. 103-104.

17 Cf. ARAÚJO, Luís Manuel de. A viagem oriental de Eça. Revista Camões n. 9/10. 2000. p. 68-74. 
Ao outro dia, que era o da festa do Beiram, recolhi ao Cairo pela hora mais quente, quando os muezins cantam a terceira oração. E ao apear do meu burro, diante do Hotel Sheperd, nos jardins do Ezbekieh, quem hei-de eu avistar? Que homem, de entre todos os homens, avistei eu no terraço, estendido numa comprida cadeira de vime, com as mãos cruzadas por trás da nuca, o «Times» esquecido sobre os joelhos, embebendo-se todo de calor e de luz? Fradique Mendes.

(...)

Durante o curto e doce momento que ali conversamos, soube que Fradique chegara havia uma semana de Suez, vindo das margens do Eufrates e da Pérsia, por onde errara, como nos contos de fadas, um ano inteiro e um dia; que tinha um debarieh, com o lindo nome de «Rosa das Águas», já tripulado e amarrado à sua espera no cais de Boulak; e que ia nele subir o Nilo até ao Alto Egito, até à Núbia, ainda para além de Ibsambul...

Todo o sol do mar Vermelho e das planícies do Eufrates não lhe tostara a pele láctea. Trazia, exatamente como no Hotel Central, uma larga quinzena preta e um colete branco fechado por botões de coral. E o laço da gravata de cetim negro representava bem, naquela terra de roupagens soltas e rutilantes, a precisão formalista das ideias ocidentais. ${ }^{18}$.

Reconhece-se na descrição do narrador o posicionamento que Edward Saïd poderia qualificar "orientalista": 19 o Cairo é o do "muezins" ou almuadens que anunciam o horário das preces; o viajante Fradique provém de Suez, após ter errado, junto às margens do Eufrates e na Pérsia, "como nos contos de fadas" por "um ano inteiro e um dia", e já se prepara para subir o Nilo e alcançar o Alto Egito e a Núbia. Mas esse flâneur internacional não se deixa contaminar pelo ambiente nada europeu, já que sua indumentária "representava bem, naquela terra de roupagens soltas e rutilantes, a precisão formalista das ideias ocidentais".

A África austral, que Fradique também visita, é aquela para onde se dirige mais adiante, na carreira literária de Eça de Queiroz, o protagonista de $A$ ilustre casa de Ramires. Mas, antes disso, o escritor conheceu o continente por meio da ficção, ao traduzir, e publicar em 1891, As minas do rei Salomão.

O romance do britânico H. Rider Haggard fora lançado em 1885, obtendo grande êxito. Narrativas de aventuras transcorridas em locais distantes, de preferência desconhecidos do público leitor europeu, à moda de $A$ ilha do tesouro, do escocês Robert Louis Stevenson, de 1883, mobilizavam o mercado editorial do período. A África austral estimulava particularmente o imaginário europeu, de um lado, por mobilizar interesses imperialistas e comerciais, de outro, por aureolar personalidades que se aventuravam por aqueles territórios distantes, como o expedicionário Richard Francis Burton, que desceu às fontes do rio Nilo, no Lago Vitória, ou o milionário Cecil Rhodes, que se adonou de boa parte das regiões que medeiam Angola e Moçambique, hoje correspondentes a Botswana, Zimbábue, Zâmbia e Malaui.

Não surpreende a circunstância de que um romance como As minas do rei Salomão fosse bem sucedido: o protagonista, Allan Quatermain, corresponde, como Richard Francis Burton, ao aventureiro destemido que adentra a África profunda, alcançando as proximidades do Zambeze e o Transvaal; a expedição que lidera estabelece o elo entre o passado mítico, representado pelo bíblico rei Salomão, e o presente, justificando, por esse meio, a posse das riquezas depositadas, pela natureza, no coração da África (matéria, mas

18 QUEIROZ, Eça de. Op. cit. p. 33-34.

19 Cf. SAÏD, Edward. Orientalismo. São Paulo: Companhia das Letras, 2007. 


\section{Conexão Letras}

em outro registro, de Joseph Conrad, cuja ficção, inaugurada por volta de 1895, explora filão similar), nada muito distinto, pois, do que fazia o colonialista Cecil Rhodes, que, na mesma ocasião, adquirira minas de diamante na atual África do Sul. ${ }^{20}$.

Eça de Queiroz responsabiliza-se pela versão de As minas do rei Salomão para a língua portuguesa. A edição original, de 1891, atribui ao romancista, de renome entre as Letras lusitanas desde meados da década de 1870, a revisão da obra, ${ }^{21}$ sugerindo que dera a palavra definitiva sobre o texto. Pode-se cogitar que, ao contrário de $A$ correspondência de Fradique Mendes, em que o narrador recupera a experiência direta do autor, na juventude turista visitante do Egito e do Oriente Médio, em A ilustre casa de Ramires, o escritor tenha sido motivado pela leitura e tradução da novela de Rider Haggard a aceitar a ideia de que seu protagonista podia migrar para Moçambique, ser bem sucedido graças à exploração das riquezas locais e retornar, exitoso, a Portugal.

A hipótese é, de certo modo, referendada pelo romance, já que, em dado momento, Ramires menciona ter intenção de migrar para a África por sugestão da leitura de As minas do rei Salomão, leitura, aliás, citada unicamente neste ponto do desenvolvimento do livro: “- Com efeito ando com uma ideia, há dias... Talvez me viesse dum romance inglês, muito interessante, e que te recomendo, sobre as antigas Minas de Ofir, King Solomon's Mines... Ando com ideias de ir para a África.. ${ }^{21}$ ".

Assim como A correspondência de Fradique Mendes, A ilustre casa de Ramires foi publicada primeiramente em revista literária e só em 1900, após o falecimento do autor, lançada em livro. Talvez Eça de Queiroz ainda buscasse conferir algum acabamento à obra, já que o protagonista desaparece subitamente antes do final da narrativa, a seguir mencionado apenas de modo indireto, por meio dos comentários dos familiares que o reencontram, após retornar da África. De todo modo, a intriga é coerente, já que os elementos que levam ao fechamento da trajetória de Ramires estão plantados ao longo de seu desenrolar.

Gonçalo Mendes Ramires, ao lado de Fradique, o outro Mendes do percurso literário de Eça de Queiroz, pertence a uma família que, como personagens e narradores fazem questão de sublinhar, é mais antiga que a nação portuguesa:

Gonçalo Mendes Ramires (como confessava esse severo genealogista, o morgado de Cidadelhe) era certamente o mais genuíno e antigo Fidalgo de Portugal. Raras famílias, mesmo coevas, poderiam traçar a sua ascendência, por linha varonil e sempre pura, até aos vagos Senhores que entre Douro e Minho mantinham castelo e terra murada quando os barões francos desceram, com pendão e caldeira, na hoste do Borguinhão. E os Ramires entroncavam limpidamente a sua casa, por linha pura e sempre varonil, no filho do Conde Nuno Mendes, aquele agigantado Ordonho Mendes, senhor de Treixedo e de Santa Ireneia, que casou em 967 com Dona Elduara, Condessa de Carrion, filha de Bermudo, o Gotoso, Rei de Leão. ${ }^{22}$.

Com efeito, seus antepassados já dominavam a região antes de D. Afonso Henriques, herdeiro de Henrique de Borgonha e fundador do reino, mover as guerras contra leoneses e castelhanos, visando garantir a autonomia do Condado Portucalense, futuro Portugal. Contudo, em seu estágio presente, a família Mendes Ramires está à beira da falência, e

20 A respeito da ação predatória de Cecil Rhodes, cf. ARENDT, Hannah. As origens do totalitarismo. São Paulo: Companhia das Letras, 1989.

21 Cf. HAGGARD, Rider. As minas de Salomão. Tradução revista por Eça de Queiroz. Porto: Livraria Internacional de Ernesto Chardron, 1891.

22 QUEIROZ, Eça de. Op. cit. p. 11-12. 
seu representante atual não parece apto a reabilitá-la financeiramente: Gonçalo é indolente, depende do arrendamento das terras por agricultores mais capazes e empreendedores, e almeja um cargo político, que lhe permita viver comodamente em Lisboa, às custas do erário público. Para tanto, precisa recuperar a notabilidade e credibilidade do clã, o que espera alcançar por meio da literatura, redigindo então um romance histórico baseado nas proezas dos ancestrais à época da fundação do Estado lusitano.

Nada, porém, do que Ramires faz é em princípio honesto: não mantém a palavra dada a José Casco, o rendeiro que primeiramente o procurou para alugar as terras aráveis do fidalgo; sua novela, $A$ torre de D. Ramires, é uma adaptação de um poema elaborado por um tio materno, que transcreve para a prosa da narrativa histórica, emulando o estilo de Alexandre Herculano:

E o trabalho, a composição moral dos vetustos Ramires, a ressurreição arqueológica do viver Afonsino, as cem tiras de almaço a atulhar de prosa forte - não o assustavam... Não! porque felizmente já possuía a "sua obra" - e cortada em bom pano, alinhavada com linha hábil. Seu tio Duarte, irmão de sua mãe (uma senhora de Guimarães, da Casa das Balsas), nos seus anos de ociosidade e imaginação, de 1845 a 1850, entre a sua carta de Bacharel e o seu Alvará de Delegado, fora poeta - e publicara no Bardo, semanário de Guimarães, um Poemeto em verso solto, o Castelo de Santa Ireneia, que assinara com duas iniciais D. B. Esse castelo era o seu, o Paço antiquíssimo de que restava a negra torre entre os limoeiros da horta. E o Poemeto cantava, com romântico garbo, um lance de altivez feudal em que se sublimara Tructesindo Ramires, Alferes-Mor de Sancho I, durante as contendas de Afonso II e das senhoras Infantas. ${ }^{23}$.

Por sua vez, sua eleição só é bem sucedida porque aceita a aliança com o até então adversário político André Cavaleiro, e isso à custa da honra de sua irmã, Gracinha: "Ele vendia, pois, o sossego da irmã, por uma cadeira em S. Bento."24

Ramires ocupa seu tempo entre a redação preguiçosa de uma novela que não o entusiasma e as conversas com os companheiros de jantares e serenatas noturnas: o Administrador do Concelho João Gouveia, Antônio Vilalobos, o Titó, e Videirinha, ajudante da farmácia, poeta e fadista. Nessas ocasiões, discutem-se a política nacional e o futuro da pátria, constando entre os temas a situação da África portuguesa, em especial a de Moçambique, manifestando-se o administrador favorável à venda de Lourenço Marques aos ingleses, e o fidalgo contra toda e qualquer atitude do governo vigente:

Depois, apenas ele findou, aclamado, e enquanto acertava as cravelhas, o Fidalgo da Torre e João Gouveia, com os cotovelos na mesa, os charutos fumegando, conversaram sobre essa venda de Lourenço Marques aos ingleses, preparada sorrateiramente (conforme clamavam, arrepiados de horror, os jornais da Oposição) pelo Governo de S. Fulgêncio. E Gonçalo também se arrepiava! Não com a alienação da colônia - mas com a impudência de S. Fulgêncio! Que aquele careca obeso, filho sacrílego dum frade que depois se fizera merceeiro em Cabecelhos, trocasse a libras, para se manter mais dois anos no poder, um pedaço de Portugal, torrão augusto, trilhado heroicamente pelos Gamas, os Ataídes, os Castros, os seus próprios avós - era para ele uma abominação que justificava todas as violências, mesmo uma revolta, e a Casa de Bragança enterrada no lodo do Tejo! ${ }^{25}$.

23 QUEIROZ, Eça de. Op. cit. p. 20. 
Na sequência da discussão, complementa o narrador, valendo-se do discurso indireto livre:

Mas o sr. Administrador do Conselho afirmou que as consentia, e rasgadamente... porque também ele, como Governo, venderia Lourenço Marques, e Moçambique, e toda a Costa Oriental! E às talhadas! Em leilão! Ali, toda a África, posta em praça, apregoada no Terreiro do Paço! E sabiam os amigos por quê? Pelo são princípio de forte administração - (estendia o braço, meio alçado do banco, como num parlamento)... Pelo são princípio de que todo o proprietário de terras distantes, que não pode valorizar por falta de dinheiro ou gente, as deve vender para consertar o seu telhado, estrumar a sua horta, povoar o seu curral, fomentar todo o bom torrão que pisa com os pés... Ora a Portugal restava toda uma riquíssima província a amanhar, a regar, a lavrar, a semear - o Alentejo! ${ }^{26}$.

De tema de debates em jantares nas tascas do local, a África converte-se em horizonte para Ramires, quando, temeroso da vingança de José Casca, a quem prometera, mas não cumprira, o arrendamento das terras, ameaça migrar para aquele continente:

- Ora se uma coisa destas se atura! Um homem que me quis matar! E agora, por cima, é sobre mim que desabam as lágrimas, e as cenas, e a criança doente! Não se pode viver nesta terra! Um dia vendo casa e quinta, emigro para Moçambique, para o Transvaal, para onde não haja maçadas... Bem, dize à mulher que já desço. ${ }^{27}$.

Essa medida concretiza-se ao final do romance, quando Ramires, enfim eleito para as Câmaras e completada a novela histórica, descobre que deveria confiar mais em suas próprias energias, em vez de se deixar conduzir pelos outros. É quando decide buscar na África sua salvação moral e econômica. Assim, ao final do capítulo XI, o narrador informa:

Gonçalo Mendes Ramires, silenciosamente, quase misteriosamente, arranjara a concessão dum vasto prazo de Macheque, na Zambézia, hipotecara a sua quinta histórica de Treixedo, e embarcava em começos de junho no paquete Portugal, com o Bento, para a África. ${ }^{28}$

A decisão surpreende, não apenas por ser tomada subitamente, mas porque a informação provém do narrador onisciente. Não se mostra qualquer participação da personagem, que se manifesta com assiduidade, em outros momentos do enredo, por meio seja do discurso direto, seja do discurso indireto livre. A partir desse ponto, Ramires desaparece da intriga, sendo o sucesso de seu empreendimento apresentado no capítulo XII, o último do romance, primeiramente por intermédio do narrador, de novo onisciente, que comenta: "Gonçalo na África, na vaga África, mandando raras cartas, mas alegres, e com um entusiasmo de fundador de Império". ${ }^{29}$

Em duas cenas subsequentes, são as demais personagens que aludem ao protagonista do romance. Na primeira delas, Ramires é citado em carta de uma personagem feminina, que mistura observações sobre moda e a aparência neo-africana do herói:

\footnotetext{
26 QUEIROZ, Eça de. Op. cit. p 33.

27 QUEIROZ, Eça de. Op. cit. p 120.

28 QUEIROZ, Eça de. Op. cit. p. 252.

29 QUEIROZ, Eça de. Op. cit. p. 253.
} 
Creio que fui eu a primeira que avistou o primo Gonçalo, na plataforma do SudExpress. Não imaginas como vem... ótimo! Até mais bonito, e sobretudo mais homem. A África nem de leve lhe tostou a pele. Sempre a mesma brancura. E duma elegância, dum apuro! Prova de como se adianta a civilização da África! dizia o primo Arega, este é estilo novo de tangas em Macheque!... [...] À noite, o José e eu jantamos em família, com o primo Gonçalo, no Bragança, para conversar da Torre e dos Cunhais. Ele contou muitas coisas interessantes da África. Traz notas para um livro, e parece que o prazo prospera. Nestes poucos anos plantou dois mil coqueiros. Tem também muito cacau, muita borracha. Galinhas são aos milhares. É verdade que uma galinha gorda em Macheque vale um pataco. Que inveja! Aqui em Lisboa custa seis tostões, só com ossos - porque tendo também alguma carne no peito, salta para cá dez tostões, e agradece! No prazo já se construiu uma grande casa, próximo do rio, com vinte janelas e pintada de azul. E o primo Gonçalo declara que já não vende o prazo nem por oitenta contos. Para felicidade completa até achou um excelente Administrador. ${ }^{30}$

A segunda cena extrapola o teor realista da narrativa, pois Gonçalo Mendes Ramires metamorfoseia-se em alegoria da nação portuguesa, conforme a interpretação de João Gouveia, um dos companheiros do protagonistas, ao tempo de suas serestas e noitadas:

- Pois eu tenho estudado muito o nosso amigo Gonçalo Mendes. E sabem vocês, sabe o Sr. Padre Soeiro quem ele me lembra?

- Quem?

- Talvez se riam. Mas eu sustento a semelhança. Aquele todo de Gonçalo, a franqueza, a doçura, a bondade, a imensa bondade, que notou o Sr. Padre Soeiro... Os fogachos e entusiasmos, que acabam logo em fumo, e juntamente muita persistência, muito aferro quando se fila à sua ideia... A generosidade, o desleixo, a constante trapalhada nos negócios, e sentimentos de muita honra, uns escrúpulos, quase pueris, não é verdade?... A imaginação que o leva sempre a exagerar até à mentira, e ao mesmo tempo um espírito prático, sempre atento à realidade útil. A viveza, a facilidade em compreender, em apanhar... A esperança constante nalgum milagre, no velho milagre de Ourique, que sanará todas as dificuldades... A vaidade, o gosto de se arrebicar, de luzir, e uma simplicidade tão grande, que dá na rua o braço a um mendigo... Um fundo de melancolia, apesar de tão palrador, tão sociável. A desconfiança terrível de si mesmo, que o acovarda, o encolhe, até que um dia se decide, e aparece um herói, que tudo arrasa... Até aquela antiguidade de raça, aqui pegada à sua velha Torre, há mil anos... Até agora aquele arranque para a África... Assim todo completo, com o bem, com o mal, sabem vocês quem ele me lembra?

- Quem?...

- Portugal. ${ }^{31}$

Na primeira cena, Ramires parece reproduzir Fradique, ao não se deixar contaminar pelo espaço africano, já que nem mesmo a pele sofreu qualquer alteração. Poder-se-ia concluir que, igualmente em A ilustre casa de Ramires, Eça aderiu ao "orientalismo" da obra anterior. Mas a segunda cena produz um descolamento entre as personagens, já que Gonçalo Mendes passa a sintetizar as características da nação lusitana, presa, de uma parte, ao passado heroico, de outro, a auspiciosas perspectivas futuras possibilitadas pela aventura africana.

A África integra-se, assim, à utopia que Eça de Queiroz constrói para Portugal, incorporando-se à identidade lusitana. E contraria, embora à distância do ponto de vista 


\section{Conexão Letras}

cronológico, a tradição originária do projeto colonialista nascido no bojo da modernidade, que lançava colonizados e adversários para o âmbito da barbárie e da primitividade.

O discurso colonial pode não ter desaparecido, mas arrefece, porque é a uma África portuguesa que Eça de Queiroz se refere. Pode requerer a desconstrução pós-colonial, mas nos termos de um resíduo, como Robert J. C. Young propõe, enquanto "um assunto não concluído, a projeção contínua dos conflitos passados na experiência do presente, a persistência insistente das imagens da memória histórica que leva ao desejo de transformar o presente". ${ }^{32}$ 